Artikel Penelitian

\title{
Kinetika Perubahan Mutu Minyak Buah Merah (Pandanus conoideus) Hasil Degumming Selama Penyimpanan
}

\section{Kinetics of Quality Change of Degummed Red Fruit (Pandanus conoideus) Oil during Storage}

Zita Letviany Sarungallo, Budi Santoso*, Meike Meilan Lisangan, Sritina Noverita Paulina Paiki, Risma Uli

Situngkir, Endah Asokawati

Program Studi Teknologi Pertanian, Fakultas Teknologi Pertanian, Universitas Papua, Manokwari

*Korespondensi dengan penulis (budsandida@yahoo.com)

Artikel ini dikirim pada tanggal 16 Juli 2018 dan dinyatakan diterima tanggal 20 November 2018. Artikel ini juga dipublikasi secara online melalui https://ejournal2.undip.ac.id/index.php/jatp. Hak cipta dilindungi undang-undang. Dilarang diperbanyak untuk tujuan komersial.

Diproduksi oleh Indonesian Food Technologists ${ }^{\circledR}$ (C2018

\begin{abstract}
Abstrak
Kandungan fosfolipid dalam minyak kasar buah merah merupakan masalah utama dalam pengolahannya menjadi berbagai produk pangan, yang dapat dihilangkan melalui proses degumming. Tujuan dari penelitian ini adalah untuk mendapatkan model kinetik perubahan kualitas minyak buah merah hasil degumming (MBMD) selama penyimpanan. MBMD dikemas dalam botol gelap dan disimpan pada suhu 60,75 , dan $90^{\circ} \mathrm{C}$ selama \pm 15 hari untuk dievaluasi kadar air, kadar asam lemak bebas (ALB), bilangan peroksida dan total karotenoid. Perubahan kualitas MBMD selama penyimpanan dihitung menggunakan persamaan Arhennius dengan perangkat lunak Microsoft Excell 2007. Hasil penelitian ini menunjukkan bahwa mutu MBMD menurun dengan meningkatnya suhu dan waktu penyimpanan. Kadar ALB dan bilangan peroksida MBMD meningkat mengikuti ordo 0, dengan energi aktivasi (Ea) 22416 dan $34839 \mathrm{~J} / \mathrm{mol}^{\circ} \mathrm{K}$. Sedangkan, penurunan kadar karotenoid sesuai dengan ordo 1 dengan Ea $48504 \mathrm{~J} / \mathrm{mol}$ ${ }^{\circ} \mathrm{K}$. Kadar ALB MBMD dengan Ea terendah adalah yang paling sensitif terhadap kerusakan hidrolisis selama penyimpanan, dibandingkan bilangan peroksida, dan kadar karotenoid. Kesimpulannya, perkiraan umur simpan MBMD berdasarkan peningkatan kadar ALB dan bilangan peroksida berhasil untuk ditentukan.
\end{abstract}

Kata Kunci: kinetika, mutu, minyak buah merah (Pandanus conoideus) degumming, penyimpanan.

\begin{abstract}
The main problem in crude red fruit oil (CRFO) is the phospholipid content. That problem can be eliminated through degumming process. The objective of this study was to obtain kinetic model of quality of degummed red fruit oil (DRFO) during storage. The DRFO was packaged in dark bottles and stored at 60,75 , and $90^{\circ} \mathrm{C}$ for \pm 15 days to evaluated of water content, free fatty acids (FFA), peroxide value and total carotenoids content. The quality change of DRFO during storage was calculated using Arhennius equation with Microsoft Excell 2007 software. The results showed that the quality of DRFO decreases with the increase of temperature and storage time. The FFA and peroxide value of DRFOs were increase following a zero order, with energy of activation (Ea) of 22416 and $34839 \mathrm{~J} / \mathrm{mol}^{\circ} \mathrm{K}$, respectively, while carotenoid content was decrease at the first order with Ea of $69009 \mathrm{~J} / \mathrm{mol}^{\circ} \mathrm{K}$. The FFA content of DRFOs (the lowest Ea) was the most sensitive to hydrolisys damaged during storage, compared to both peroxide value and carotenoid content. As conclusion, the shelf life estimation of the DRFO based on the increasing of both FFA and peroxide values were successfully formulated.
\end{abstract}

Keywords: Kinetics, quality, red fruit (Pandanus conoideus) oil degummed, storage.

\section{Pendahuluan}

Minyak buah merah (Pandanus conoideus) mengandung berbagai komponen aktif yang meliputi $a-$ karoten, $\beta$-karoten, $\beta$-kriptosantin, dan a-tokoferol, serta asam lemak tidak jenuh, terutama asam oleat, linoleat, linolenat dan palmitoleat (Sarungallo et al. 2015a; Sarungallo et al. 2015b), yang sangat berpotensi untuk diolah menjadi pangan fungsional. Walaupun demikian hasil ekstraksi buah merah tersebut merupakan minyak kasar yang juga mengandung fosfolipid dan komponen tidak murni lainnya seperti asam lemak bebas (ALB), pigmen, sterol, dan digliserida. Kandungan fosfolipid dalam minyak mentah merupakan masalah utama selama proses pengolahan minyak buah merah menjadi berbagai produk olahan lain seperti emulsi dan mikrokapsul, yang dapat dihilangkan melalui proses degumming. Menurut Sengar et al., (2014) tujuan utama degumming adalah untuk mencegah adanya endapan dalam minyak kasar selama penyimpanan atau pengangkutan, mencegah pengasaman gum-gum, sebagai tahap penyaringan minyak secara fisik, mengurangi kehilangan minyak selama netralisasi, dan menghasilkan lesitin secara komersial.

Proses degumming minyak dapat dilakukan dengan berbagai metode baik secara kimia maupun fisik, antara lain menggunakan air, $\mathrm{NaCl}$, asam sulfat, asam fosfat atau asam sitrat 0.05-0.2\% (Anderson 2005; De dan Patel 2010), enzim (Mukherjee et al., 2013), serta teknologi membran (Coutinho et al., 2009). Namun penggunaan asam terbukti efektif dalam biaya dan banyak variasi yang telah dikembangkan untuk meningkatkan konsistensi hasilnya (Anderson, 2005). Degumming menggunakan 0,2-2\% $\mathrm{H}_{2} \mathrm{PO}_{4}$ dan asam sitrat (Murtiningrum et al., 2011) dilaporkan efektif 
menurunkan kadar fosfor minyak buah merah. Degumming minyak kasar buah merah dengan menggunakan asam sitrat $0,2 \%$, dapat menurunkan kadar fosfor dan meningkatkan kadar $\beta$-karoten dan $\alpha$ tokoferol, dengan komposisi asam lemak tidak jenuh minyak yang masih tinggi $(67,7 \%)$ yang didominasi oleh asam oleat, asam lionoleat dan asam linolenat (Murtiningrum et al., 2011).

Kandungan asam lemak minyak buah merah hasil degumming masih cukup tinggi sehingga sangat mudah teroksidasi selama penyimpanan dan dapat mempengaruhi mutu minyak. Perubahan mutu minyak buah merah tersebut dapat dikendalikan dengan membuat model kinetika reaksinya dengan memprediksi atribut kualitas minyak pada berbagai proses pengolahan panas, kondisi penyimpanan, dan distribusi (van Boekel, 2008). Sarungallo et al., (2018) melaporkan bahwa peningkatan kadar ALB dan bilangan peroksida minyak buah merah kasar mengikuti ordo nol, dengan nilai Ea berturut-turut 43318 dan $29437 \mathrm{~J} / \mathrm{mol}^{\circ} \mathrm{K}$; sedangkan penurunan kadar karotenoid mengikuti ordo 1 dengan nilai Ea $66783 \mathrm{~J} / \mathrm{mol}^{\circ} \mathrm{K}$. Dengan semikian minyak buah merah kasar paling sensitif terhadap kerusakan oksidatif selama penyimpanan karena memiliki nilai Ea terrendah. Perilaku kinetika oksidasi pada minyak buah merah hasil degumming selama penyimpanan sebagai fungsi waktu sangat diperlukan agar kestabilan kualitasnya dapat dikendalikan. Penelitian ini bertujuan untuk mendapatkan model kinetika perubahan (kestabilan) mutu minyak buah merah hasil degumming selama penyimpanan pada suhu tinggi.

\section{Materi dan Metode}

Bahan baku utama yang digunakan dalam penelitian ini adalah minyak buah merah yang diekstrak menggunakan cara basah (Sarungallo et al., 2014). Bahan kimia yang digunakan adalah berbagai bahan kimia dengan analytical grade untuk analisa kadar ALB, bilangan peroksida, dan total karotenoid. Peralatan yang digunakan untuk analisis minyak buah merah antara lain timbangan analitik, oven, hot plate, water bath, alat titrasi, spektrofotometer (Shimadzu UV-2450, Kyoto, Jepang), serta peralatan gelas lainnya.

\section{Deguming minyak buah merah}

Proses degumming, menggunakan metode yang dikembangkan oleh Mayamol (2007) yang dimodifikasi, diawali dengan pemanasan minyak buah merah kasar (MBMK) sebanyak $250 \mathrm{ml}$ dalam penangas suhu $60^{\circ} \mathrm{C}$, penambahan asam sitrat $2 \%$ dan diaduk selama 5 menit. Selanjutnya penambahan air dan diaduk menggunakan magnetic stirrer. Pemisahan minyak hasil degumming, air dan gum dilakukan secara sentrifugasi. Minyak hasil degumming yang telah dipisahkan selanjutnya dinetralkan kembali menggunakan air, sampai air pencuciannya netral $(\mathrm{pH} 7)$. Minyak buah merah degumming yang dihasilkan dikemas dalam botol gelap untuk dianalisis dan diuji stabilitasnya selama penyimpanan pada suhu tinggi.
Tabel 1. Perlakuan suhu $\left({ }^{\circ} \mathrm{C}\right)$ dan lama penyimpanan minyak buah merah hasil degumming

\begin{tabular}{cccccccc} 
Suhu & \multicolumn{7}{c}{ Lama penyimpanan (jam) } \\
\hline 60 & 0 & 12 & 36 & 72 & 132 & 216 & 336 \\
75 & 0 & 10 & 34 & 72 & 120 & 192 & 240 \\
90 & 0 & 6 & 24 & 48 & 84 & 180 & 200 \\
\hline
\end{tabular}

Uji stabilitas oksidasi MBMD

Minyak buah merah hasil degumming yang diuji stabilitas oksidasinya dikemas dalam botol berwarna gelap dan disimpan selama \pm 15 hari pada suhu 60,75 , dan $90{ }^{\circ} \mathrm{C}$. Periode pengamatan pada setiap suhu dilakukan seperti yang disajikan pada Tabel 1. Analisa minyak yang diuji dilakukan terhadap mutu MBMD yaitu kadar air, ALB, bilangan peroksida, dan total karotenoid. Pelaksanaan tahapan penelitian ini menggunakan Rancangan Acak Lengkap (RAL) dengan 2 ulangan, dengan pengamatan secara triplo sehingga total sebanyak 6 satuan percobaan.

\section{Analisis mutu kimia minyak}

Analisis mutu kimia MBMD yaitu kadar air berdasarkan pada metode sebelumnya (AOCS, 2003), kadar ALB ditentukan berdasarkan metode titrasi (AOCS, 2003) dan bilangan peroksida menggunakan metode asam asetat-chloroform (AOCS, 2003); sedangkan pengukuran total karotenoid menggunakan metode Knockaert et al. (2012) dengan sedikit modifikasi. Sebanyak $0,01 \mathrm{~g}$ minyak buah merah, ditambahkan 0,1\% butylated hydroxytoluene (BHT) dan heksan dalam labu ukur $10 \mathrm{ml}$ sampai tanda tera dan divortek. Selanjutnya absorbansi diukur dengan spektrofotometer pada panjang gelombang $470 \mathrm{~nm}$ dengan menggunakan heksan yang ditambahkan 0,1\% BHT sebagai blanko. Total karotenoid dihitung menggunakan perhitungan konsentrasi karotenoid (Persamaan 1).

Konsentrasi karotenoid $\left(\frac{\mathrm{mg}}{\mathrm{kg}}\right)=\frac{\mathrm{A} \times \operatorname{volume}\left(\mathrm{ml} \times 10^{4}\right)}{\mathrm{E}_{1 \mathrm{~cm}}^{1 \%} \mathrm{x} \text { berat sampel }(\mathrm{g})}$

Keterangan:

A adalah absorbansi pada panjang gelombang $470 \mathrm{~nm}$, volume adalah total volume larutan sampel, $\mathrm{E}_{1 \mathrm{~cm}}^{1 \%}$ adalah extinction coefficient yaitu 2560 untuk $\beta$-karoten dalam heksan (Hart dan Scott 1995).

\section{Analisis Umur Simpan}

Analisis data perubahan mutu MBMD selama penyimpanan untuk menghasilkan model kinetika dilakukan menggunakan persamaan Arrhenius dengan software Microsoft Excell 2007. Perubahan mutu minyak buah merah selama penyimpanan pada suhu konstan tertentu dapat dijelaskan dengan Persamaan $2(A=$ $A o+k t)$ dan Persamaan $3(\ln A=\ln A o+k t)$ yang merupakan persamaan untuk reaksi ordo 0 dan ordo 1 , berturut-turut; dimana $A=$ konsentrasi $(\mathrm{ppm}), \quad k=$ konstanta laju reaksi ( $1 /$ hari), $t=$ waktu reaksi (hari) (Toledo, 2007). Dari persamaan 2-1 diperoleh nilai konstanta laju reaksi $(k)$ sebagai fungsi suhu $(T)$. Representasi reaksi perubahan mutu minyak dipilih berdasarkan koefisien determinasi $\left(R^{2}\right)$ yang tertinggi dari persamaan regresinya.

Pengaruh suhu terhadap kecepatan reaksi perubahan mutu minyak selama penyimpanan 
menggunakan persamaan Arrhenius pada Persamaan 4 yaitu $\ln k=\ln A-(E a / R T)$, dimana $k=$ konstanta laju reaksi, $A=$ faktor pre-eksponensial (mol/L det), $E_{a}=$ energi aktivasi $(\mathrm{kJ} / \mathrm{mol}), R=$ konstanta gas ideal $(8,315$ $\mathrm{kJ} / \mathrm{mol}^{\circ} \mathrm{K}$ ), dan $T=$ suhu $\left({ }^{\circ} \mathrm{K}\right)$ (Toledo, 2007).

Energi aktivasi $\left(E_{a}\right)$ dan faktor pre-eksponensial atau faktor frekuensi $(A)$, masing-masing ditentukan dari slope dan intersep, dari garis yang dihasilkan oleh regresi linier antara In $k$ dan $1 / T$.

\section{Hasil dan Pembahasan}

Perubahan Asam Lemak Bebas

Kualitas minyak nabati utamanya ditentukan oleh kandungan ALB yang bertanggung jawab terhadap perkembangan flavor tengik yang tidak dikehendaki (hydrolytic rancidity) karena sangat mudah teroksidasi selama penyimpanan (Bhosle dan Subramanian 2005). Minyak buah merah degumming yang digunakan dalam kajian ini memiliki kadar ALB yaitu 0,71\%, yang masih di bawah standar kadar ALB untuk CPO (crude palm oil) sebesar 5\% (SNI, 1992), namun lebih tinggi dari standar minyak makan yaitu 0,3\% (SNI, 2002).

Data kadar ALB MBMD ini lebih tinggi dibandingkan MBMK, yang merupakan hasil penelitian sebelumnya yaitu sebesar $0,57 \%$ (Sarungallo et al., 2018). Peningkatan kadar ALB ini diduga karena dalam proses degumming menggunakan asam sitrat $2 \%$, sehingga kemungkinan besar MBMK mengalami reaksi hidrolisis lemak, terutama selama tahap pencucian. Sarungallo et al., (2009) juga melaporkan bahwa proses degumming minyak buah merah kasar menggunakan asam sitrat $0,2 \%$, tidak menurunkan kadar ALB minyak yang dihasilkan. Demikian halnya dengan laporan Wei et al., (2004) bahwa proses degumming menggunakan asam fofat dan bleaching menggunakan acid-activated clays cenderung meningkatkan ALB minyak sawit.

Selama penyimpanan pada suhu tinggi $(60,75$ dan $\left.95^{\circ} \mathrm{C}\right)$, kadar ALB minyak degumming buah merah cenderung meningkat mencapai 1,35-1,40\% (Figur 1a). Kecenderungan ini sama dengan penelitian sebelumnya yaitu kadar ALB MBMK (0,57\%) selama penyimpanan meningkat, namun peningkatannya lebih tinggi yaitu 1,57-1,82\% (Sarungallo et al., 2018). Hasil ini membuktikan bahwa proses degumming sangat mempengaruhi kestabilan minyak terhadap reaksi hidrolisis selama penyimpanan.

Kadar ALB MBMD ini juga dapat disebabkan karena tersedianya air dalam minyak di awal penyimpanan yaitu $3,9 \%$, yang dapat memicu terjadinya hidrolisis. Walaupun demikian, kadar air tersebut mengalami penurunan selama penyimpanan, yaitu mencapai 0,39-0,51\% (Figur 2).

Penurunan kadar air diduga disebabkan karena selama penyimpanan pada suhu tinggi terjadi reaksi hidrolisis minyak yang melibatkan air. Kadar air awal MBMD ini lebih tinggi dibandingkan MBMK sebesar $0,85 \%$, yang cenderung meningkat selama penyimpanan pada suhu tinggi $\left(90^{\circ} \mathrm{C}\right)$ dan pada akhir pengamatan mencapai 4,34\% (Sarungallo et al., 2018). Adanya perbedaan kadar air awal pada MBMK dan
MBMD dapat mempengaruhi perbedaan kinetika yaitu laju reaksi (nilai k) penurunan mutu minyak.
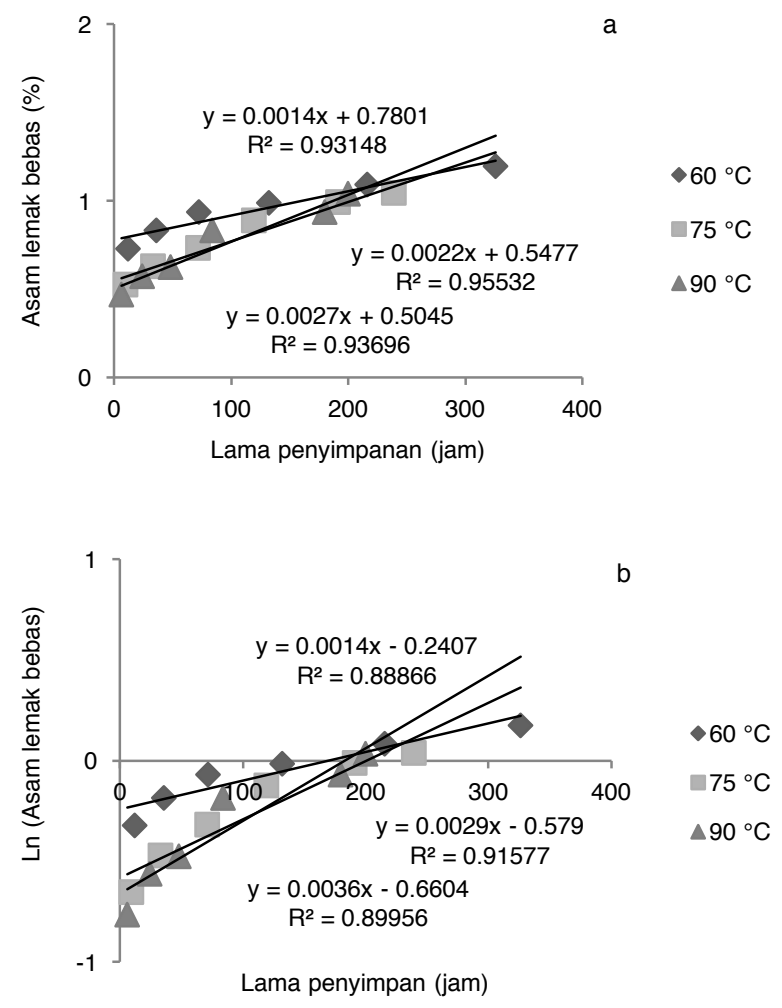

Figur 1. Orde reaksi perubahan kadar asam lemak bebas minyak buah merah hasil degumming; (a) reaksi ordo 0; (b) reaksi ordo 1

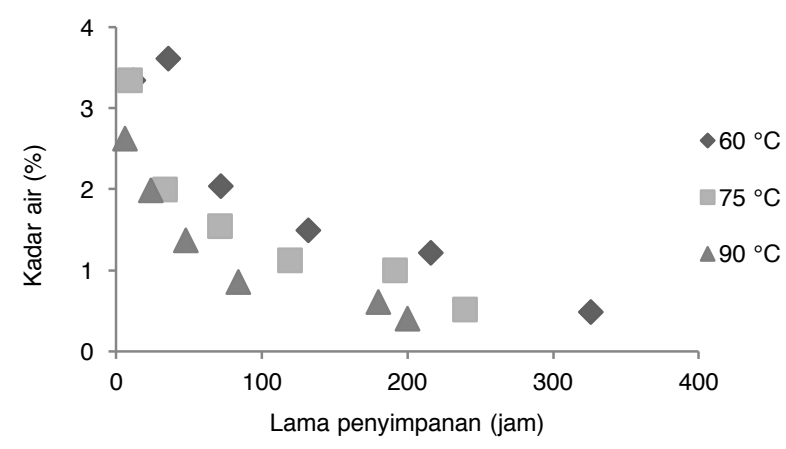

Figur 2. Penurunan kadar air minyak buah merah hasil degumming pada suhu 60,75 dan $90^{\circ} \mathrm{C}$ selama penyimpanan

Kondisi penyimpanan yang buruk, enzim menjadi aktif dan asam-asam lemak sangat mudah terurai menjadi rantai pendek (ALB) yang dapat menghasilkan off-flavor serta menurunkan kualitas minyak, akibat serangan hidrolitik yang dapat menjadi masalah selama penyimpanan dan transportasi minyak (Bockisch 1998). Hal yang sama juga dilaporkan oleh Ayustaningwarno (2010) bahwa adanya ALB sangat mempengaruhi oksidasi minyak sawit merah yang dinetralisasi (NDRPO), yang terjadi pada awal oksidasi dan prosesnya sangat dipengaruhi oleh keberadaan air dan suhu tinggi. 

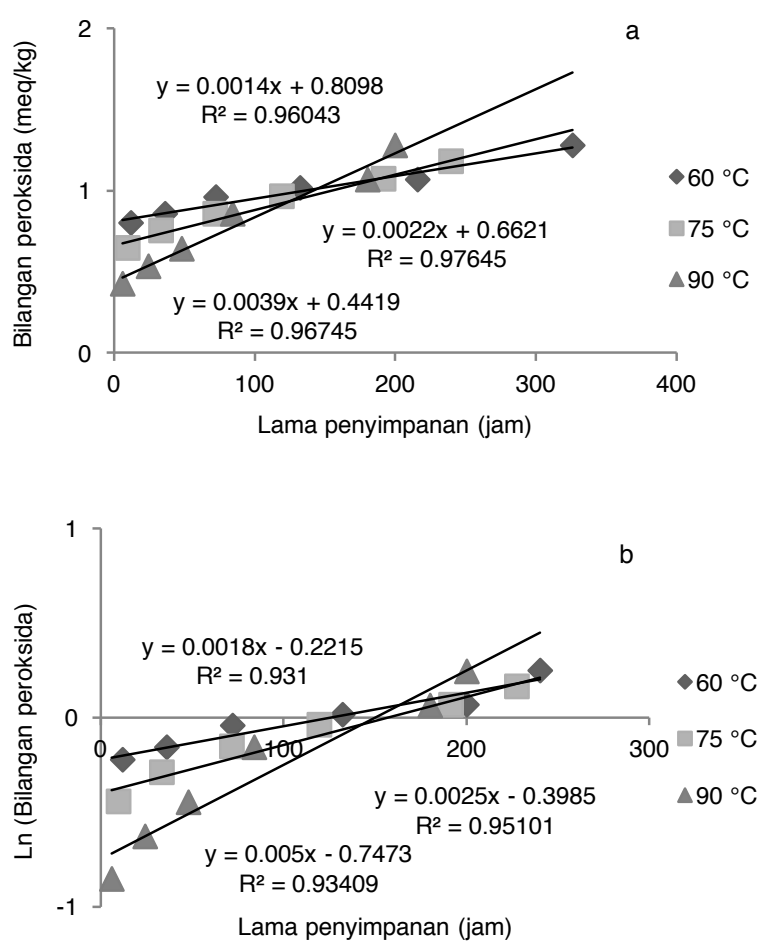

Figur 3. Orde reaksi perubahan bilangan peroksida minyak buah merah hasil degumming; (a) reaksi ordo 0; (b) reaksi ordo 1

\section{Perubahan Bilangan Peroksida}

Bilangan peroksida umumnya digunakan untuk mengukur oksidasi lemak. Secara teoritis, oksidasi lemak merupakan reaksi rantai radikal bebas antara lemak tidak jenuh dan oksigen menghasilkan peroksida, yang dapat terjadi karena berada dalam sistim katalitik seperti cahaya, panas, enzim, logam, metaloprotein, dan mikroorganisme (Shahidi dan Zhong, 2005). Bilangan peroksida MBMD sekitar $0,39 \mathrm{meq} / \mathrm{kg}$, sedangkan standar SNI bilangan peroksida untuk minyak makan adalah $2 \mathrm{meq} / \mathrm{kg}$ (SNI 2002). Bilangan peroksida MBMD ini lebih rendah dibandingkan dengan minyak buah merah kasar (MBMK) yaitu $0,53 \mathrm{meq} / \mathrm{kg}$ (Sarungallo et al., 2018). Hal ini mengindikasikan bahwa aplikasi proses degumming dapat menurunkan tingkat oksidasi minyak buah merah.

Proses degumming minyak buah merah kasar menggunakan asam sitrat $0,2 \%$, dapat menurunkan bilangan peroksida minyak yang dihasilkan (Sarungallo et al., 2009). Wei et al. (2004) menjelaskan pula bahwa proses degumming menggunakan asam fofat dan bleaching dengan acid-activated clays dapat menghilangkan semua produk primer oksidasi minyak sehingga menurunkan bilangan peroksida minyak sawit tersebut. Penggunaan asam fosfat $2 \%$ dapat menurunkan bilangan peroksida dari minyak pangan nabati (minyak kelapa dan minyak kacang tanah) kasar dari $1,8 \mathrm{meq} / \mathrm{kg}$ menjadi $0,017 \mathrm{meq} / \mathrm{kg}$. Hasil pengamatan perubahan bilangan peroksida MBMD pada suhu 60,75 dan $95^{\circ} \mathrm{C}$ disajikan pada Figur 3 .

Figur 3 juga menunjukan bahwa bilangan peroksida MBMD meningkat dengan meningkatnya suhu dan lama waktu penyimpanan. Data ini tidak berbeda dengan penelitian sebelumnya yaitu terjadi peningkatan bilangan peroksida MBMK yang disimpan pada kondisi yang sama (Sarungallo et al., 2018). Namun peningkatan bilangan peroksida MBMK lebih cepat dibandingkan MBMD, yang diindikasikan oleh nilai Ea MBMK sebesar 29,437 $\mathrm{J} / \mathrm{mol}^{\circ} \mathrm{K}$ lebih kecil, sehingga dengan energi yang sangat kecil sudah dapat terjadi reaksi oksidasi dibandingkan Ea MBMD sebesar 34,839 $\mathrm{J} / \mathrm{mol}{ }^{\circ} \mathrm{K}$ (Sarungallo et al., 2018). Hal ini membuktikan bahwa proses degumming dapat mempertahankan kestabilan minyak terhadap oksidasi. Iwuoha et al. (1996) juga melaporkan bahwa penggunaan asam fosfat $2 \%$ dapat meningkatkan kualitas minyak pangan nabati (minyak kelapa dan minyak kacang tanah) dibandingkan dengan minyak kasar.

\section{Perubahan Total Karotenoid}

Karotenoid merupakan pigmen yang berperan terhadap warna merah pada minyak buah merah, yang diindikasikan dengan kadarnya yang sangat tinggi (Surono et al., 2008; Sarungallo et al., 2015). Kadar total karotenoid MBMD pada hari ke-0 adalah 5610 ppm, lebih rendah dibandingkan dengan MBMK yaitu 7857 ppm (Sarungallo et al., 2018). Proses degumming dapat menurunkan kadar karotenoid minyak buah merah yang dihasilkan yang dimungkinkan karena selama degumming terdapat tahapan pencucian minyak buah merah menggunakan air hangat dan sentrifugasi, yang dapat menyebabkan isomerisasi dan degradasi karotenoid (Knockaert et al., 2012; Zeb, 2012).
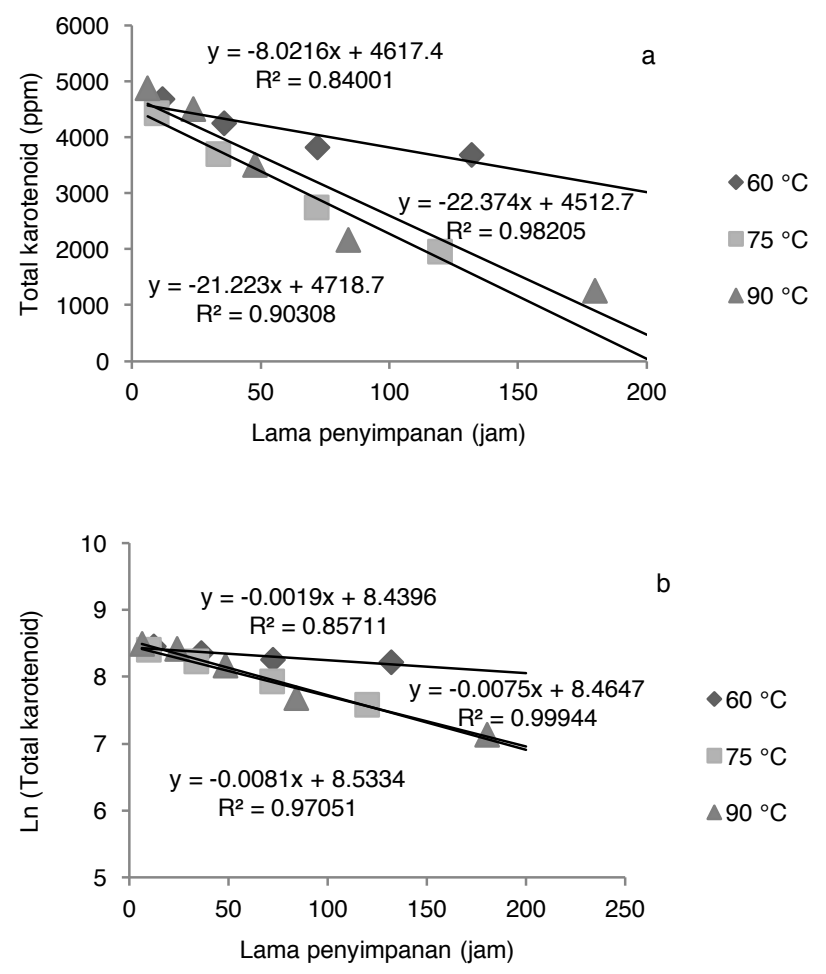

Figur 4. Orde reaksi perubahan Total Karotenoid minyak buah merah hasil degumming; (a) reaksi ordo 0 ; (b) reaksi ordo 1

Perubahan kadar total karotenoid MBMD selama penyimpanan pada suhu 60,75 , dan $95^{\circ} \mathrm{C}$ cenderung mengalami penurunan (Figur 4). Penurunan kadar karotenoid MBMD pada suhu $60^{\circ} \mathrm{C}$ lebih rendah dibandingkan dengan suhu 75 dan $90^{\circ} \mathrm{C}$, yang dalam 
Tabel 2. Hasil regresi nilai k dan In k dari reaksi perubahan kadar Asam Lemak Bebas (ALB), bilangan peroksida dan total karotenoid minyak dari buah merah hasil degumming pada suhu 60,75 dan $90^{\circ} \mathrm{C}$ selama penyimpanan

\begin{tabular}{|c|c|c|c|c|c|c|}
\hline \multicolumn{7}{|c|}{ Perubahan kadar Asam Lemak Bebas (ALB) } \\
\hline \multirow{2}{*}{$\begin{array}{l}\text { Suhu, } \\
\mathrm{T}\left({ }^{\circ} \mathrm{C}\right)\end{array}$} & \multirow{2}{*}{$\begin{array}{l}\text { Suhu, } \\
\mathrm{T}\left({ }^{\circ} \mathrm{K}\right)\end{array}$} & \multirow[t]{2}{*}{$1 / T$} & \multirow[t]{2}{*}{ nilai $\mathrm{k}$} & \multirow[t]{2}{*}{ In $\mathrm{k}$} & \multicolumn{2}{|c|}{ Regresi In k dan 1/T } \\
\hline & & & & & Persamaan linier $^{\mathrm{a}}$ & Nilai Ea ${ }^{\mathrm{b}}$ \\
\hline 60 & 333,15 & 0,003002 & 0,0014 & $-6,595$ & $y=-2696,2 x+1,5$ & $22416 \mathrm{~J} / \mathrm{mol}^{\circ} \mathrm{K}$ \\
\hline 75 & 348,15 & 0,002872 & 0,0022 & $-6,103$ & & \\
\hline 90 & 363,15 & 0,002754 & 0,0027 & $-5,930$ & & \\
\hline \multicolumn{7}{|c|}{ Perubahan Bilangan Peroksida } \\
\hline \multirow{2}{*}{$\begin{array}{l}\text { Suhu, } \\
\mathrm{T}\left({ }^{\circ} \mathrm{C}\right)\end{array}$} & \multirow{2}{*}{$\begin{array}{l}\text { Suhu, } \\
\mathrm{T}\left({ }^{\circ} \mathrm{K}\right)\end{array}$} & \multirow[t]{2}{*}{$1 / \mathrm{T}$} & \multirow[t]{2}{*}{ nilai $\mathrm{k}$} & \multirow[t]{2}{*}{$\ln \mathrm{k}$} & \multicolumn{2}{|c|}{ Regresi In k dan 1/T } \\
\hline & & & & & Persamaan linier $^{\mathrm{C}}$ & Nilai $\mathrm{Ea}^{\mathrm{d}}$ \\
\hline 60 & 333,15 & 0,003002 & 0,0014 & $-6,578$ & $y=-4190,5 x+5,9$ & $34839 \mathrm{~J} / \mathrm{mol}^{\circ} \mathrm{K}$ \\
\hline 75 & 348,15 & 0,002872 & 0,0022 & $-6,129$ & & \\
\hline 90 & 363,15 & 0,002754 & 0,0039 & $-5,536$ & & \\
\hline \multicolumn{7}{|c|}{ Perubahan Total Karotenoid } \\
\hline \multirow{2}{*}{$\begin{array}{l}\text { Suhu, } \\
\mathrm{T}\left({ }^{\circ} \mathrm{C}\right)\end{array}$} & \multirow{2}{*}{$\begin{array}{l}\text { Suhu, } \\
\mathrm{T}\left({ }^{\circ} \mathrm{K}\right)\end{array}$} & \multirow[t]{2}{*}{$1 / T$} & \multirow[t]{2}{*}{ nilai $\mathrm{k}$} & \multirow[t]{2}{*}{$\ln \mathrm{k}$} & \multicolumn{2}{|c|}{ Regresi In k dan 1/T } \\
\hline & & & & & Persamaan linier $^{\mathrm{e}}$ & Nilai Ea ${ }^{\dagger}$ \\
\hline 60 & 333,15 & 0,003002 & $-0,0019$ & $-6,243$ & $y=-5834,4 x+11,5$ & $48504 \mathrm{~J} / \mathrm{mol}{ }^{\circ} \mathrm{K}$ \\
\hline 75 & 348,15 & 0,002872 & $-0,0075$ & $-4,892$ & & \\
\hline 90 & 363,15 & 0,002754 & $-0,0081$ & $-4,814$ & & \\
\hline \multicolumn{7}{|c|}{$\begin{array}{l}\text { Intersep merupakan nilai A yaitu } 1,5 \text {, maka untuk perubahan ALB, nilai Ao }=\text { eksp } 1,5 \text {. } \\
\text { Kemiringan grafik (slope) merupakan nilai - Ea/R yaitu } 2696 \text {, jika R: konstanta gas }\left(8,314 \mathrm{~J} / \mathrm{mol}{ }^{\circ} \mathrm{K}\right) \text {, } \\
=2696 \times 8,314 \mathrm{~J} / \mathrm{mol}{ }^{\circ} \mathrm{K}=22416,2 \mathrm{~J} / \mathrm{mol}{ }^{\circ} \mathrm{K} \text {. } \\
\text { Untuk perubahan bilangan peroksida, Nilai Ao }=\text { eksp } 5,9 \\
\text { Untuk perubahan bilangan peroksida, nilai - Ea/R yaitu } 4190,5 x \text {, maka Nilai Ea }=34839,8 \mathrm{~J} / \mathrm{mol}^{\circ} \mathrm{K} \\
\text { Untuk perubahan karotenoid, nilai Ao }=\text { eksp } 11,5 \\
\text { Untuk perubahan karotenoid, nilai - Ea/R yaitu }-5834 \text {, maka Nilai Ea }=48504 \mathrm{~J} / \mathrm{mol}{ }^{\circ} \mathrm{K} .\end{array}$} \\
\hline
\end{tabular}

jangka waktu yang relatif singkat yaitu masing-masing 100 dan 200 jam dengan kadar karotenoidnya sudah di bawah 2000 ppm (Figur 4). Disamping itu, penurunan kadar karotenoid MBMD ini lebih tinggi dibandingkan dengan MBMK, yang pada penyimpanan 200 jam kadar karotenoid pada semua suhu, masih diatas 2000 ppm (Sarungallo et al., 2018), sehingga terbukti bahwa proses degumming menyebabkan karotenoid minyak buah merah menjadi lebih sensitif terhadap suhu tinggi.

Proses degumming cenderung menurunkan intensitas warna minyak pangan nabati (minyak kelapa dan kacang) menjadi lebih muda (Iwuoha et al., 1996). Menurut Chen et al. (1995) dan Wilska-Jeszka (2002), karoten terdegradasi oleh asam. Dijelaskan pula bahwa mekanisme degradasi karoten merupakan proses protonasi yang dapat terjadi pada asam dengan kekuatan sedang. Karoten yang telah mengalami tahap terprotonasi dapat terdegradasi secara perlahan ke molekul dengan sistem konjugasi yang lebih pendek (Mortensen dan Skibsted, 2000). Oleh karena itu, sangat memungkinkan degradasi karotenoid selama proses degumming disebabkan oleh adanya asam. You et al. (2001) juga melaporkan bahwa proses degumming menyebabkan reduksi karotenoid $1,67 \mathrm{mg}$ dari total karoten dan 55,67 ppm dari konsentrasi karotenoid dari CPO; yang diduga karena terdegradasinya karotenoid selama proses degumming.

\section{Kinetika Perubahan Mutu MBMD}

Model kinetik menggambarkan perubahan mutu dengan model matematika yang mengandung karakteristik parameter kinetik seperti energi aktivasi (Ea) dan laju konstanta (k) (van Boikei, 2008). Penentuan ordo reaksi merupakan tahap awal untuk mengevaluasi perubahan mutu MBDM, yang didasarkan pada nilai $\mathrm{R}^{2}$ dari persamaan regresinya. Semakin tinggi nilai $R^{2}$, maka dapat diartikan semakin tinggi linieritasnya yang juga menunjukkan bahwa model matematika dapat lebih akurat dalam memprediksi nilai mutu yang sebenarnya. Perubahan kadar ALB, bilangan peroksida dan total karotenoid MBMD masing-masing disajikan pada Figur 1, 3, dan 4.

Figur 1 dan 3 memperlihatkan bahwa ordo reaksi peningkatan kadar ALB dan bilangan peroksida minyak buah merah diperoleh pada ordo 0 ; sedangkan model degradasi karotenoid berdasarkan pada ordo 1 (Figur 4). Reaksi orde 0 dicirikan dengan hubungan linier antara konsentrasi reaktan dengan waktu reaksi (Toledo, 2004). Hasil ini sama dengan penelitian sebelumnya yang melaporkan bahwa peningkatan kadar ALB dan bilangan peroksida dari MBMK mengikuti ordo 0 , sedangkan penurunan kadar karotenoid mengikuti ordo 1 (Sarungallo et al., 2018). Ayustaningwarno (2010) juga melaporkan bahwa perubahan kadar ALB minyak sawit merah yang dinetralisasi (NDRPO) terus menurun secara konstan mengikuti ordo 0 selama penyimpanan, yang menunjukkan bahwa laju reaksi tersebut tidak tergatung pada konsentrasi.

Nilai k mengindikasikan laju reaksi perubahan mutu MBMD. Data pada Tabel 2 memperlihatkan bahwa semakin tinggi suhu penyimpanan, laju perubahan (nilai k) mutu MBMD juga semakin meningkat; dimana nilai $\mathrm{k}$ terbesar dihasilkan oleh penurunan total karotenoid (0,0019-0,0112), sedangkan yang terendah pada peningkatan kadar ALB (0,0014-0,0027). Dengan demikian maka kecepatan reaksi degradasi karotenoid pada MBMD lebih tinggi dibandingkan reaksi oksidasi maupun reaksi hidrolisis selama penyimpanan suhu tinggi. Hasil ini berbeda dengan kecepatan reaksi perubahan mutu pada MBMK yang disimpan pada suhu 
yang sama, dimana kecepatan reaksi oksidasinya lebih tinggi dibandingkan reaksi hidrolisis maupun degradasi karotenoid (Sarungallo et al., 2018). Hal ini menunjukkan bahwa proses degumming dengan metode asam dapat menekan peningkatan ALB, namun di sisi lain dapat menurunkan stabilitas karotenoid minyak buah merah selama penyimpanan pada suhu tinggi.

Nilai Ea menunjukkan energi yang diperlukan untuk perubahan atribut mutu suatu produk pangan. Data pada Tabel 2 memperlihatkan bahwa dari semua parameter mutu MBMD, nilai Ea yang terendah dimiliki oleh kadar ALB, yang mengindikasikan bahwa MBMD sangat mudah terhidrolisis dari pada teroksidasi. Berbeda dengan hasil penelitian sebelumnya, yang melaporkan bahwa MBMK memiliki nilai Ea perubahan kadar ALB sebesar $37709 \mathrm{~J} / \mathrm{mol}{ }^{\circ} \mathrm{K}$ (Sarungallo et al., 2018) lebih besar dibandingkan nilai Ea dari MBMD sebesar $22416 \mathrm{~J} / \mathrm{mol}^{\circ} \mathrm{K}$ (Tabel 2). Dengan demikian proses degumming pada minyak buah merah meningkatkan sensitivitasnya terhadap reaksi hidrolisis dibandingkan minyak kasarnya.

Perubahan kadar karotenoid MBMD sebagai komponen antioksidan relatif membutuhkan waktu yang lebih lama untuk terdegradasi dengan nilai Ea yang tertinggi dibandingkan kadar ALB dan bilangan peroksida, yang menunjukkan kecenderungan yang sama dengan stabilitas karotenoid pada MBMK (Sarungallo et al., 2018). Walaupun demikian dari data pada Tabel 2, terlihat bahwa nilai Ea perubahan karotenoid pada MBMD sebesar $48504 \mathrm{~J} / \mathrm{mol}{ }^{\circ} \mathrm{K}$, lebih kecil dibandingkan MBMK dengan nilai Ea sebesar $78113 \mathrm{~J} / \mathrm{mol}{ }^{\circ} \mathrm{K}$ (Sarungallo et al., 2018). Hal ini mengindikasikan bahwa proses degumming cenderung untuk menurunkan stabilitas karotenoid minyak buah merah selama penyimpanan pada tinggi. Fenomena ini diduga karena gum (fosfolipid) yang merupakan komponen pengotor atau kontaminan dalam minyak buah merah, namun keberadaannya dalam MBMK justru bertindak sebagai pelindung bagi komponen aktif terhadap paparan suhu tinggi selama penyimpanan.

Berdasarkan data yang terdapat pada Tabel 2, dengan menggunakan rumus pada Persamaan 3, maka dihasilkan persamaan yang dapat digunakan untuk menduga umur simpan berdasarkan parameter: peningkatan kadar ALB minyak buah merah, yaitu: $A=$ In $A_{o}-\left(\right.$ t. eksp $\left.{ }^{[1,5-2696(1 / T)]}\right)$; peningkatan bilangan peroksida adalah: $A=A_{0}-(t$. eksp $[5,9-4191(1 / T)])$; sedangkan untuk penurunan kadar karotenoid yaitu: $A=$ In $A_{o}-\left(t^{[11,5-5834(1 / T)]}\right)$, dimana A: kadar (mutu) akhir; Ao: kadar (mutu) awal; t: lama penyimpanan (jam); dan $\mathrm{T}$ : suhu penyimpanan $\left({ }^{\circ} \mathrm{K}\right)$.

\section{Kesimpulan}

Mutu minyak buah merah degumming (MBMD) menurun dengan meningkatnya suhu dan lama penyimpanan, yang dicirikan dengan meningkatnya kadar ALB dan bilangan peroksida, serta menurunnya kadar total karotenoidnya. Peningkatan kadar ALB dan bilangan peroksida MBMD mengikuti ordo 0; sedangkan penurunan kadar karotenoid sesuai dengan ordo 1. Kadar ALB minyak buah merah dengan Ea terendah dinilai paling sensitif terhadap kerusakan hidrolisis selama penyimpanan, dibandingkan bilangan peroksida dan kadar karotenoid. Persamaan pendugaan umur simpan minyak buah merah berdasarkan parameter: peningkatan kadar ALB juga dapat ditentukan persamaannya.

\section{Ucapan Terima Kasih}

Peneliti mengucapkan terima kasih kepada Kementerian Riset, Teknologi, dan Pendidikan Tinggi atas dana yang diberikan melalui Hibah Penelitian Strategis Nasional tahun 2016, dengan nomor kontrak 059/SP2H/DRPM/II/2016, tgl. 17-02-2016.

\section{Daftar Pustaka}

Anderson, D. 2005. A Primer on Oils Processing Technology. Dalam: Shahidi, F. (Editor). Edible Oil and Fat Products: Processing Technologies. Bailey's Industrial Oil and Fat Products, $6^{\text {th }}$ ed., Volume 5. John Wiley \& Sons, Inc., New Jersey.

AOCS (American Oil Chemists' Society). 2003. Official Methods and Recommended Practices of the AOCS. $5^{\text {th }}$ edition. AOCS, Champaign, USA.

Ayustaningwarno, F. 2010. Kinetika Parameter Stabilitas Oksidasi Minyak Sawit Merah. Tesis-Program Pascasarjana. Institut Pertanian Bogor, Bogor.

Bhosle,,B.M., Subramanian, R. 2005. New approaches in deacidification of edible oil (a review). Journal of Food Engineering 69: 481-494. DOI: 10.1016/ j.jfoodeng.2004.09.003.

Bockisch, M. 1998. Fats and Oils Handbook. AOCS Press.Champaign, Illinois.

Chen, B. H., Peng, H. Y., Chen, H. E. 1995. Changes of carotenoids, colour and vitamin A contents during processing of carrot juice. Journal of Agricultural and Food Chemistry 43(3):1912-1918. DOI: 10.1021/jf00055a029.

Coutinho, C.D.M., Chiu, M.C., Basso, R.C., Ribeiro, A.P.B., Gonçalves, L.A.G., Viotto, L.A. 2009. State of art of the application of membrane technology to vegetable oils: A review. Food Research International 42: 536-550. DOI: 10.1016/j.foodres.2009.02.010.

De, B.K., Patel, J.D. 2010. Effect of different degumming processes and some nontraditional neutralizing agent on refining of $\mathrm{RBO}$. Journal of Oleo Science 5(3):121- 125. DOI: 10.5650/jos.59.121.

Hart, D.J., Scott, K.J. 1995. Development and evaluation of an HPLC method for the analysis of carotenoids in foods, and the measurement of the carotenoid content of vegetables and fruits commonly consumed in the UK. Food Chemistry 54: 101111. DOI: 10.1016/0308-8146(95)92669-B.

Iwuoha, C.I., Collins, N. Ubbaonu, Rophina C. Ugwo, Ngozi U. Okereke. 1996. Chemical and physical characteristics of palm, palm kernel and groundnut oils as affected by degumming. Food Chemistry 55(1):29-34. DOI: 10.1016/03088146(95)00067-4.

Knockaert, G., Lemmens, L., Van-Buggenhout, S., Hendrickx, M., Van-Loey, A. 2012. Changes in $\beta-$ 
carotene bioaccessibility and concentration during processing of carrot puree. Food Chemistry 133: 60-67. DOI: 10.1016/j.foodchem.2011.12.066.

Mayamol, P.N., Balachandran, C., Samuel, T. , Sundaresan, A., Arumughan, C. 2007. Process technology for the production of micronutrient rich red palm olein. Journal of the American Oil Chemist Society. 84: 587-596. DOI: 10.1007/s11746-007-1078-9.

Mortensen, A., Skibsted, L. H. 2000. Kinetics and mechanism of the primary steps of degradation of carotenoids by acid in homogenous solution. Journal of Agricultural and Food Chemistry 48 (2): 279-286. DOI: 10.1021/jf9904620.

Mukherjee, A.K., Mondal, K., Akhan, M.A.I., Biswas, S. 2013. Effects of Phospholipase A2 degumming on Palm Oil components. International Journal of Agricultural and Food Science 3(2): 69-71.

Murtiningrum, Sarungallo, Z. L., Roreng, M.K.. 2011. Kandungan komponen aktif minyak kasar dan hasil degumming dari buah merah (pandanus conoideus) yang diekstrak secara tradisional. Dalam: Montolalu, R. I., Andarwulan, N., ljong, F.G., Tooy, D., Djarkasi, G.S.S., Mentang, F., Makapedua, D.M. (editor). Prosiding Seminar Nasional Perhimpunan Ahli Pangan Indonesia (PATPI), 15-17 September 2011 di Manado, Sulawesi Utara, Indonesia. p. 157-160. ISBN: 978-602-98902-1-1.

Sarungallo, Z. L., P. Hariyadi, N. Andarwulan, E. H. Purnomo. 2014. Pengaruh metode ekstraksi terhadap mutu kimia dan komposisi asam lemak minyak buah merah (Pandanus conoideus). Teknologi Industri Pertanian 24(3):209-217.

Sarungallo, Z.L., B. Santoso, Tethool, E.F., Situngkir, R.U., Tupamahu, J. 2018. Kinetika perubahan mutu minyak buah merah (Pandanus conoideus) selama penyimpanan. Agritech 38(1):64-70. DOI: 10.22146/agritech.25216.

Sarungallo, Z.L., Hariyadi, P., Andarwulan, N., Purnomo, E.H. 2015a. Analysis of $a$-cryptoxanthin, $\beta$ cryptoxanthin, $a$-carotene, and $\beta$-carotene of Pandanus conoideus oil by high-performance liquid chromatography (HPLC). Procedia Food Science 3: 231-243. DOI: 10.1016/j.profoo. 2015.01.026

Sarungallo, Z.L., Hariyadi, P., Andarwulan, N., Purnomo, E. H. 2015b. Characterization of chemical properties, lipid profile, total phenol and tocopherol content of oils extracted from nine clones of red fruit (Pandanus conoideus). Kasetsart Journal (Nature Science) 49: 237-250.

Sarungallo, Z.L., Murtiningrum, Paiki, S.N.P. 2009. Sifat Fisikokimia Minyak Kasar dan Hasil Degumming dari Buah Merah (Pandanus conoideus L.) yang diekstrak secara tradisional Merdey. Jurnal Agrotek 1(6):9-15.

Sengar, G., Kaushal, P., Sharma, H. K., Kaur, M. 2014. Degumming of rice bran oil. Reviews in Chemical Engineering 30(2): 183-198. DOI: 10.1515/revce2013-0030.

Shahidi, F., Zhong, W. 2005. Lipid Oxidation: Measurement Methods. Dalam: Shahidi, F. (Editor). Bailey's Industrial Oil and Fat Products, $6^{\text {th }}$ ed., Volume 6 . John Wiley \& Sons, Inc., New Jersey.

SNI (Standar Nasional Indonesia) 01-2901-1992, Minyak Kelapa Sawit. 1992. Badan Standarisasi Nasional, Jakarta.

SNI (Standar Nasional Indonesia) 01-3741-2002, Minyak goreng. 2002. Badan Standarisasi Nasional, Jakarta.

Surono, I., Endaryanto, T.A., Nishigaki, T. 2008. Indonesian biodiversities, from microbes to herbal plants as potential functional foods. Journal of the Faculty of Agriculture Shinshu University 44(1.2):23-27.

Toledo, R.T. 2007. Fundamentals of Food Process Engineering, $3^{\text {th }}$ edition. Springger, New York.

van Boekel, M.A.J.S. 2008. Kinetic modelling of food quality: A Critical Review. Comprehensive Review of Food Science dan Food safety 7:144-156. DOI: 10.1111/j.1541-4337.2007.00036.x.

Wei, P.C., May, C.Y., Ngan, M. A., Hock, C.C. 2004. Degumming and bleaching: effect on selected constituents of palm oil. Journal of Oil Palm Research 16 (2): 57-63.

Wilska-Jeszka, J. 2002. Food Colorants. Dalam: Sikorski, Z.E. (ed.), Chemical and Functional Properties of Food Components. Second Edition, CRC Press, New York.

You, L., Bahari, B.S., Che Man, Y.B., Takagi, S. 2001. Effect of degumming process on chromatographic separation of carotenes from crude and degummed palm oil. Journal of Food Lipids 8(1):27-35. DOI: 10.1111/j.1745-4522.2001. tb00181.x.

Zeb, A. 2012. Oxidation and formation of oxidation products of $\beta$-carotene at boiling temperature. Chemistry and Physics of Lipids. 165: 277-281. DOI: 10.1016/j.chemphyslip.2012.02.005. 